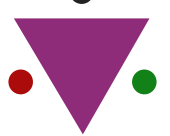

IJCRR

Section: Healthcare

Sci. Journal Impact

Factor: 6.1 (2018)

ICV: 90.90 (2018)

(c) (1) (3)

Copyright@IJCRR

\section{Awareness on Self Isolation to Prevent COVID 19 Infection Among Elderly People of Tamilnadu - A Survey}

\author{
Shradha Jalan ${ }^{1}$, R. Gayathri², V. Vishnu Priya ${ }^{3}$, Kavitha S. ${ }^{4}$
}

'Saveetha Dental College and Hospitals, Saveetha Institute of Medical and Technical Sciences (SIMATS), Saveetha University, Chennai 77, India; 2Assistant Professor, Department of Biochemistry, Saveetha Dental College and Hospitals, Saveetha Institute of Medical and Technical Sciences, Saveetha University, Chennai 77, Tamilnadu, India; ${ }^{P}$ rofessor, Department of Biochemistry, Saveetha Dental College, Saveetha Institute of Medical and Technical Sciences, Saveetha University, Chennai 77, Tamilnadu, India; ${ }^{4}$ Lecturer, Department of Biochemistry, Saveetha Dental College, Saveetha Institute of Medical and Technical Sciences, Saveetha University, Chennai 77, Tamilnadu, India.

\title{
ABSTRACT
}

Introduction: COVID-19 is a respiratory syndrome affecting countless numbers of lives all over the world. It is reportedly caused due to the SARS-CoV-2 virus which is known to impair the lower respiratory tract causing distress. Usually affects the aged population and people with less immunity. Thus, it becomes important to make the elderly population aware of the effects of COVID infections. The study aims at analyzing the awareness of the precautions to be taken to avoid the infection among citizens.

Materials and Methods: A questionnaire was distributed through an online Google form link to about 100 people, who are more than 50 years of age. The study population was asked to fill out the online form after reading each question thoroughly.

Results: The results were collected and the data was analyzed using SPSS version 20. From the survey, it is evident that most of the elderly people are aware of the importance of self-isolation as a preventive measure to fight COVID infection.

Conclusion: This study gives an insight into the public perception towards the awareness of self-isolation to fight COVID-19 among elderly people.

Key Words: COVID-19, Elderly people, Public perception, Self isolation, Quarantine, Survey.

\section{INTRODUCTION}

COVID-19 is a respiratory syndrome affecting countless numbers of lives all over the world. Elderly people can stay at the home and home quarantine themselves. ${ }^{1,2}$. They should contact medical advisors if required and should stay isolated at home ${ }^{3,4}$. COVID-19 is a viral infectious disease that can infect mostly the elderly people due to their low immunity power ${ }^{5}$. Old age people are already prone to increased risk of cardiovascular, autoimmune, and mental health problems $\mathrm{s}^{6,7}$. When seeing their vulnerability it is better to avoid going out and meeting people avoid hand shaking ${ }^{8,9}$. COVID infection is exhibited by respiratory illness, fatigue, fever, sore throat, and tiredness ${ }^{10,11}$. Elderly people are more prone to get infected from COVID-19 Human coronavirus attacks the upper respiratory tract ranging from mild to moderate severity ${ }^{12,13}$. It is studied that people with low immunity. ${ }^{14,15}$ power are more prone to get infected ${ }^{16,17}$. COVID-19 prone areas are kept under quarantine and long lockdown. They have closed all the schools, colleges, public places, and companies, in which Tamil Nadu has the highest cases compared to other states ${ }^{18,19}$. Till now, there are no vaccines discovered to cure COVID-19. But there are necessarily strict precautions to be taken ${ }^{20,21}$. COVID-19 cannot be transmitted in hot climates. As a precaution people are advised to wear masks and gloves. They are also advised to maintain social distance use alcohol-based hand sanitizer. Avoid touching, hugging, and handshaking with other people. ${ }^{22,23}$

In this current situation, when there are no treatment methods or vaccines available to protect people, it becomes very important to prevent the community from diseases. Having known that the sector of people who are prone are elderly and sick people, it becomes important, that a proper awareness to be created to keep them healthy. ${ }^{24}$

\section{Corresponding Author:}

Dr. R. Gayathri, Lecturer, Department of biochemistry, Saveetha dental College and Hospitals, Saveetha Institute of Medical and Technical Sciences (SIMATS) Velapanchavadi, Chennai-600077, Tamilnadu, India; Phone: 9710680545; Email: gayathri.sdc@saveetha.com

ISSN: 2231-2196 (Print)

Received: 25.07 .2020
ISSN: $0975-5241$ (Online)

Revised: 20.08 .2020
Accepted: 26.09 .2020
Published: 20.10 .2020 
This study is done in order to spread awareness on self-isolation as a preventive measure to fight COVID-19 infection among the elderly population. It mainly focuses on analyzing the general public's perspective about the precautions they should take.

\section{MATERIALS AND METHODS}

\section{Study Design}

A survey was conducted among elderly people (age more than 50) to evaluate the knowledge, awareness, and perception of self-isolation procedures to be followed during a pandemic. The sampling method is a simple random sampling method. The sample size of the study is 165 . The participants did the survey voluntarily and no incentives were given to them. Ethical approval and informed consent from the participants were obtained. The study was conducted in the month of May, 2020.

\section{Survey Instrument}

The survey instrument which was a questionnaire was prepared after an extensive review of the existing literature. The questionnaire was reviewed and amendments were made to improve clarity of the questions to eliminate ambiguous responses. The questionnaire consisted of a total of 12 questions. The questionnaire was shared to the participants using an online survey platform using the following link "https://docs.google.com/forms/d/e/1FAIpQLSdEHueiIWvlBFmGilXloJaHftzJEPRQZIyTvBo-B0Hp8y7dw/ viewform?usp=sf_link"

\section{Data Analysis}

Only completed surveys were taken for analysis and the incomplete surveys were eliminated. The statistical test used is descriptive statistics. All the responses obtained were tabulated and the reliability of the data was checked. A bar graph with a frequency table was prepared and analyzed for each question using SPSS data analysis software.

A questionnaire containing questions related to creating awareness on the increasing spread of COVID infection was distributed through an online Google forms link to about 100 elderly people. The study population was asked to fill out the online form after reading each question thoroughly. The results were collected and the data was analyzed using SPSS version 20.

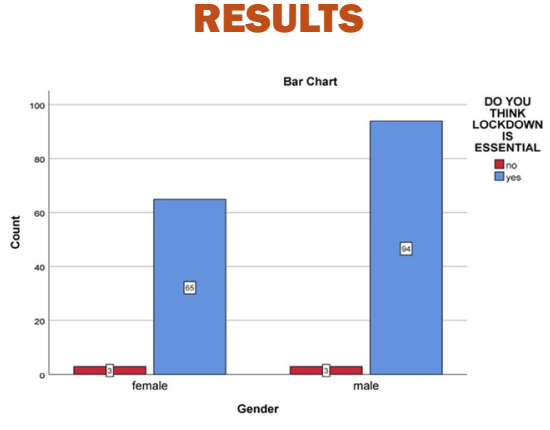

Figure 1: Bar chart showing the correlation between gender and opinion on whether the lockdown is essential. Bar graph representing the individual opinion on whether the lockdown is essential based on gender. $\mathrm{X}$-axis represents Gender, Y-axis represents individuals who are aware (blue) and unaware (red). 94 out of 97 male participants, 65 out of 68 female participants feel lockdown is essential. Gender doesn't seem to influence opinion towards keeping them safe. Pearson's Chi-square value: 0.16, DF- $1, p$-value $=0.899$ $(>0.05)$, and it was not statistically significant.

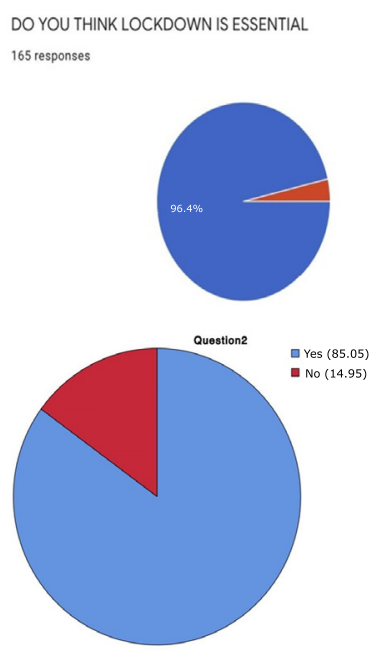

Figure 2: Figure represents the distribution of participants based on their opinion towards maintaining social distancing among friends and family members, where $85.05 \%$ (blue) of the study participants feel that social distancing to be maintained even among friends and family members and $14.95 \%$ (red) of them feel that it is not necessary.

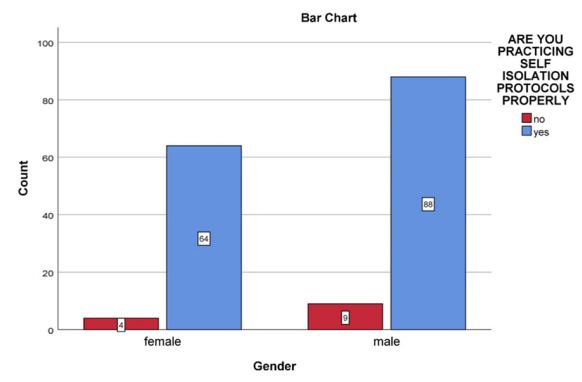

Figure 3: Bar chart showing the correlation between gender and whether they are practicing self-isolation protocols strictly. 
Bar graph represents the individual opinion on whether they are practicing self-isolation protocols based on gender. X-axis represents Gender, Y-axis represents individuals who are practicing (blue) and not practicing (red). 88 out of 97 male participants and 64 out of 68 female participants agree that they strictly follow self-isolation protocols. Gender doesn't seem to influence the safety protocol. Pearson's Chi-square analysis $=0.775$, DF- $1, p$-value $=0.379$ $(>0.05)$, and it was not statistically significant.

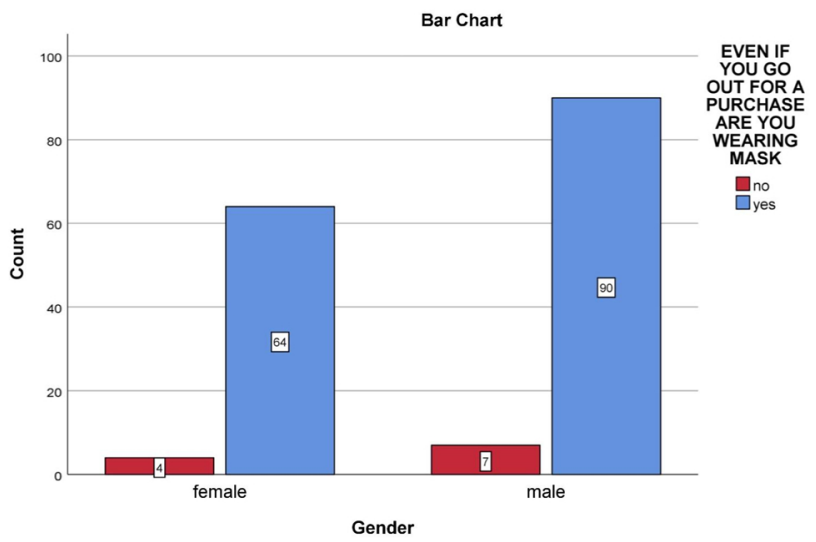

Figure 4: Bar chart showing the correlation between gender and whether they are wearing masks when they go out. The bar graph represents the individual opinion on whether they wear a mask while going out based on gender. X-axis represents Gender, Y-axis represents individuals who are aware (blue) and unaware (red). 90 out of 97 male participants, 64 out of 68 female participants agree that they strictly wear masks while going out. Gender doesn't seem to influence the safety protocol. Pearson's Chi-square analysis $=1.274, \mathrm{DF}-1, \mathrm{P}$-value $=0.259$ $(>0.05)$, and it was not statistically significant.

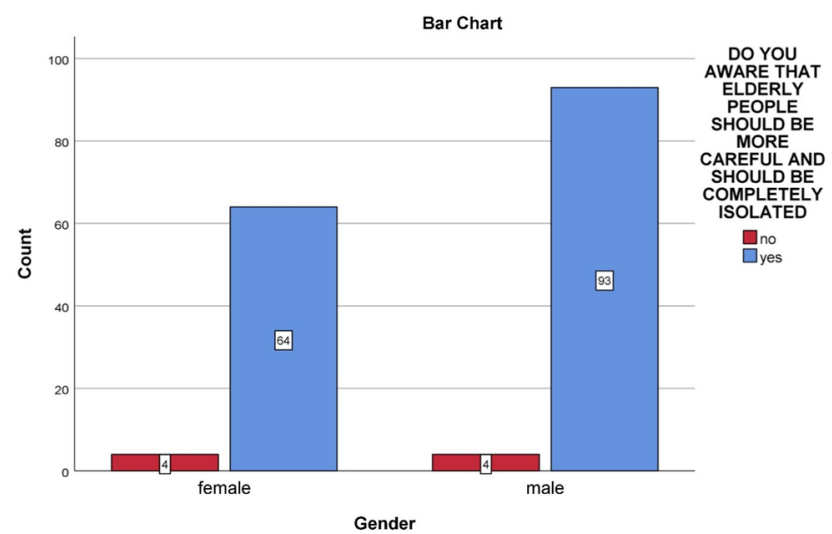

Figure 5: Bar chart showing the correlation between gender and the opinion on being careful as they are more prone to get infected. Bar graph represents the individual opinion on whether they are aware that they are more prone to infection as they are elderly based on gender. X-axis represents Gender, Y-axis represents individuals who are aware (blue) and unaware (red). 93 out of 97 male participants and 64 out of 68 female participants agree that they are more prone to infection Pearson's Chi-square analysis $=0.240$, DF- 1, P-value $=$ 0.624 (>0.05), and it was not statistically significant.

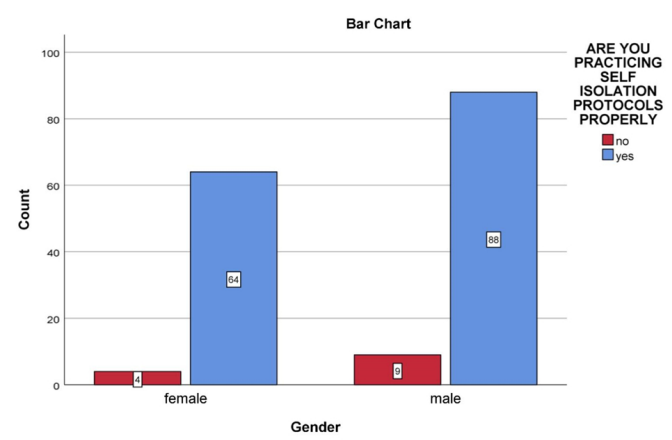

Figure 6: Bar chart showing the correlation between gender and their willingness to spread awareness on self-isolation protocols to others.

The bar graph represents the individual opinion on whether they are willing to spread awareness on self-isolation to others based on gender. X-axis represents Gender, Y-axis represents individuals who are willing (blue) and not willing (red). 88 out of 97 male participants and 64 out of 68 female participants agree that they are willing to spread awareness to their friends. Though statistically not significant, females are more likely to spread awareness among their community. Pearson's Chi-square analysis $=0.240$, DF -1, P-value $=0.624$ $(>0.05)$, and it was not statistically significant.

\section{DISCUSSION}

From the study population (100\%) around $70 \%$ answered positively when asked whether lockdown is essential (Fig. 1 ), thus in the bar graph representing Chi-square analysis between gender and their opinion towards lockdown 38 males and 32 females supported for lockdown, the P-value was 0.899 and it was not statistically significant. According to the previous, the elderly are more prone to get infected because of their low immune. About $90.3 \%$ of the study population are aware that they should not go out and get contacted with other people, and must follow social distancing (Fig. 2). About $95.2 \%$ of the participants answered positively when asked whether while sleeping also social distancing is important. According to the article elderly people are more prone to get infected because many have cardiovascular-related problems ${ }^{25,26}$. When asked about the self-isolation protocols around $92.1 \%$ of the respondents answered positively (Fig. 3). In the bar graph representing Chi-square analysis between gender and awareness on practicing self-isolation, 50 male participants and 45 female participants were aware 
of it. The P-value was 0.375 and it was not statistically significant. The study population was asked a question whether they feel lonely, about $93.3 \%$ of the population answered that they feel lonely, but at the same time understood the need of the hour too. According to the previous study, elderly people usually feel lonely in some unstable situations ${ }^{27}$. A question was raised on whether they wear masks when they go out, to which $93.3 \%$ of respondents answered positively (Fig. 4). In the bar graph representing Chi-square analysis between gender and awareness on wearing masks, about 50 males and 42 females were aware of it, The P-value was 0.259 and it was not statistically significant. A question was asked whether elderly people have high chances to get infected and around $95.2 \%$ of the study population answered that older people have more chances to get infected due to weak immune systems (Fig. 5). In the bar graph representing Chi-square analysis between gender and awareness of high risk of being infected, 49 males and 42 females were aware of it, the P-value was 0.624 and it was not statistically significant. According to the previous study, elderly people have less blood flow rate and $\mathrm{RBC}$ count as their age increases and might be a reason for making them prone to various infections. ${ }^{28-30}$. About $92.7 \%$ of the population answered positively when asked about whether they teach or instruct their friends and family members about the safety measures they should take to avoid infection (Fig. 6). In the bar graph representing Chisquare analysis between gender and willingness to spread awareness 52 males and 42 females were interested to spread awareness. The P-value was 0.624 and it was not statistically significant. When asked whether lockdown prevails in our country, about $95.1 \%$ of the population answered that they are well aware of the government instructed lockdown. According to the previous article, elderly people are more sensitive and always want to know things going around. ${ }^{31}$. When asked about whether the survey was useful around 93.9\%. The study population said it was very useful.

The future scope of this study focuses on helping the population in understanding the public perception regarding the self-isolation of elderly people. It also focuses on ensuring the knowledge of various preventive measures that can be taken in order to prevent the acquisition of the virus thereby leading to the betterment of health and lifestyle of the elderly population.

\section{CONCLUSION}

COVID-19 is thought to infect host cells through ACE-2 to cause COVID-19 while also damaging to myocardium. Selfisolation will affect elderly individuals whose social contact is out of the home, such as the daycare venues, community centers, and places of worship. Elderly people should remain home, have groceries and vital medications delivered, and should avoid social contact with family and friends. Self- isolation among elderly people is a serious public health concern because of their heightened risk of cardiovascular, autoimmune, and mental health problems. This study gives an insight of the public perception towards the awareness of self-isolation among elderly people.

\section{ACKNOWLEDGMENT}

Authors acknowledge the immense help received from the scholars whose articles are cited and included in references to this manuscript. The authors are also grateful to authors / editors / publishers of all those articles, journals, and books from which the literature for this article has been reviewed and discussed.

\section{Conflict of interest}

Nil

\section{Funding Information}

None

\section{REFERENCES}

1. Anirudh BVM, Gayathri R, Priya VV. Attitude of schoolchildren on the use of gadgets on academics. Drug Invention Today. 2018 Aug 1;10(8):1411-3.

2. Li Z, Veeraraghavan VP, Mohan SK, Bolla SR, Lakshmanan H, Kumaran S, et al. Apoptotic induction and anti-metastatic activity of eugenol encapsulated chitosan nanopolymer on rat glioma C6 cells via alleviating the MMP signaling pathway. J Photochem Photobiol B. 2020 Jan;203:111773.

3. Shukri NMM, Vishnupriya V, Gayathri R, Mohan SK. Awareness in childhood obesity [Internet]. Vol. 9, Research Journal of Pharmacy and Technology. 2016. p. 1658. Available from: http:// dx.doi.org/10.5958/0974-360x.2016.00334.6

4. Wang Y, Zhang Y, Guo Y, Lu J, Veeraraghavan VP, Mohan SK, et al. Synthesis of Zinc oxide nanoparticles from Marsdenia tenacissima inhibits the cell proliferation and induces apoptosis in laryngeal cancer cells (Hep-2). J Photochem Photobiol B. 2019 Dec;201:111624.

5. Rengasamy G, Venkataraman A, Veeraraghavan VP, Jainu M. Cytotoxic and apoptotic potential of Myristica fragrans Houtt. (mace) extract on human oral epidermal carcinoma KB cell lines [Internet]. Vol. 54, Brazilian Journal of Pharmaceutical Sciences. 2018. Available from: http://dx.doi.org/10.1590/s217597902018000318028

6. M G, Geetha M, Seshadri LN. COVID-19: A "Violent" pandemic for health care workers in India [Internet]. Vol. 1, COVID-19 Special Issue. 2020. p. 32-40. Available from: http://dx.doi. org/10.18231/j.ijirm.2020.023

7. Menon A, V VP, Gayathri R. Preliminary Phytochemical Analysis and Cytotoxicity Potential of Pineapple Extract on Oral Cancer Cell Lines [Internet]. Asian Journal of Pharmaceutical and Clinical Research. 2016. p. 140. Available from: http://dx.doi. org/10.22159/ajpcr.2016.v9s2.13313

8. Roe K. COVID-19 infection thrombosis due to hemagluttination of antibodies and COVID-19 antigens bound to erythro- 
cytes [Internet]. Available from: http://dx.doi.org/10.22541/ au. 158872328.86968358

9. Mohan SK, Veeraraghavan VP, Jainu M. Effect of pioglitazone, quercetin, and hydroxy citric acid on vascular endothelial growth factor messenger RNA (VEGF mRNA) expression in experimentally induced nonalcoholic steatohepatitis (NASH) [Internet]. Vol. 45, TURKISH JOURNAL OF MEDICAL SCIENCES. 2015. p. 542-6. Available from: http://dx.doi.org/10.3906/ sag-1404-136

10. Reethega V, Vishnu Priya V, Gayathri R. Cytotoxicity potential of flaxseed oil on oral cancer cell lines. International Journal of Research in Pharmaceutical Sciences. 2018 Apr 27;9(2):430-3.

11. Cho HJ, Feldman LS, Keller S, Hoffman A, Pahwa AK, Krouss M. Choosing Wisely in the COVID-19 Era: Preventing Harm to Healthcare Workers. J Hosp Med [Internet]. 2020 May 21; Available from: http://dx.doi.org/10.12788/jhm.3457

12. Gan H, Zhang Y, Zhou Q, Zheng L, Xie X, Veeraraghavan VP, et al. Zingerone induced caspase-dependent apoptosis in MCF7 cells and prevents 7,12-dimethylbenz(a)anthracene-induced mammary carcinogenesis in experimental rats [Internet]. Vol. 33, Journal of Biochemical and Molecular Toxicology. 2019. Available from: http://dx.doi.org/10.1002/jbt.22387

13. Grover S, Sahoo S, Rani S, Shah R, Singh A, Mehra A. COVID-19 pandemic-related anxiety in teenagers [Internet]. Vol. 62, Indian Journal of Psychiatry. 2020. p. 328. Available from: http://dx.doi.org/10.4103/psychiatry.indianjpsychiatry_327_20

14. Wu F, Zhu J, Li G, Wang J, Veeraraghavan VP, Mohan SK, et al. Biologically synthesized green gold nanoparticles from Siberian ginseng induce growth-inhibitory effect on melanoma cells (B16) [Internet]. Vol. 47, Artificial Cells, Nanomedicine, and Biotechnology. 2019. p. 3297-305. Available from: http:// dx.doi.org/10.1080/21691401.2019.1647224

15. Ma Y, Karunakaran T, Veeraraghavan VP, Mohan SK, Li S. Sesame Inhibits Cell Proliferation and Induces Apoptosis through Inhibition of STAT-3 Translocation in Thyroid Cancer Cell Lines (FTC-133) [Internet]. Vol. 24, Biotechnology and Bioprocess Engineering. 2019. p. 646-52. Available from: http:// dx.doi.org/10.1007/s12257-019-0151-1

16. Ke Y, Al Aboody MS, Alturaiki W, Alsagaby SA, Alfaiz FA, Veeraraghavan VP, et al. Photosynthesized gold nanoparticles from Catharanthus roseus induces caspase-mediated apoptosis in cervical cancer cells (HeLa) [Internet]. Vol. 47, Artificial Cells, Nanomedicine, and Biotechnology. 2019. p. 1938-46. Available from: http://dx.doi.org/10.1080/21691401.2019.1614017

17. Jainu M, Priya V, Mohan S. Biochemical evidence for the antitumor potential of Garcinia mangostana Linn. On diethylnitrosamine-induced hepatic carcinoma [Internet]. Vol. 14, Pharmacognosy Magazine. 2018. p. 186. Available from: http://dx.doi. org/10.4103/pm.pm_213_17

18. Zahar T. Covid-19: Everything about Handwashing and Coronavirus: Clean hands, clean virus. Bs Lê Trọng Đại; 20 p.

19. Chen F, Tang Y, Sun Y, Veeraraghavan VP, Mohan SK, Cui C. 6-shogaol, a active constiuents of ginger prevents UVB radiation mediated inflammation and oxidative stress through modulating $\mathrm{NrF} 2$ signaling in human epidermal keratinocytes (HaCaT cells) [Internet]. Vol. 197, Journal of Photochemistry and Photobiology B: Biology. 2019. p. 111518. Available from: http://dx.doi. org/10.1016/j.jphotobiol.2019.111518

20. Gideon Informatics, Inc., Berger S. COVID-19, MERS and SARS: Global Status. GIDEON Informatics Inc; 2020.
21. Duan X, Wu T, Liu T, Yang H, Ding X, Chen Y, et al. Vicenin-2 ameliorates oxidative damage and photoaging via modulation of MAPKs and MMPs signaling in UVB radiation exposed human skin cells [Internet]. Vol. 190, Journal of Photochemistry and Photobiology B: Biology. 2019. p. 76-85. Available from: http:// dx.doi.org/10.1016/j.jphotobiol.2018.11.018

22. Saxena SK. Coronavirus Disease 2019 (COVID-19): Epidemiology, Pathogenesis, Diagnosis, and Therapeutics. Springer Nature; $2020.213 \mathrm{p}$.

23. Ma A, Zhang R. Diosmetin Inhibits Cell Proliferation, Induces Cell Apoptosis and Cell Cycle Arrest in Liver Cancer [Internet]. Vol. 12, Cancer Management and Research. 2020. p. 3537-46. Available from: http://dx.doi.org/10.2147/cmar.s240064

24. Ponnulakshmi R, Shyamaladevi B, Vijayalakshmi P, Selvaraj J. In silicoandin vivoanalysis to identify the antidiabetic activity of beta sitosterol in adipose tissue of high fat diet and sucrose induced type-2 diabetic experimental rats [Internet]. Vol. 29, Toxicology Mechanisms and Methods. 2019. p. 276-90. Available from: http://dx.doi.org/10.1080/15376516.2018.1545815

25. Rengasamy G, Jebaraj DM, Veeraraghavan VP, Mohan SK. Characterization, Partial Purification of Alkaline Protease from Intestinal Waste of Scomberomorus Guttatus and Production of Laundry Detergent with Alkaline Protease Additive. Indian Journal of Pharmaceutical Education and Research [Internet]. 2016 [cited 2020 Jun 6];50(2s). Available from: https://www. google.co.in/url? sa $=\mathrm{t} \& \mathrm{rct}=\mathrm{j} \& \mathrm{q}=\&$ esrc $=\mathrm{s} \&$ source $=$ web $\& \mathrm{~cd}=\& \mathrm{v}$ ed=2ahUKEwiv9_6ku-zpAhVSzTgGHToQAtoQFjAAegQIAx AB\&url=https $\% 3 \mathrm{~A} \% 2 \mathrm{~F} \% 2 \mathrm{Fwww} . \mathrm{ijper}$.org $\% 2$ Farticle $\% 2 \mathrm{~F} 413$ \&usg=AOvVaw3Lf2DBB5fI8DhSODTqd4Nj

26. Trogen B, Gonzalez FJ, Shust GF. COVID-19-Associated Myocarditis in an Adolescent. Pediatr Infect Dis J [Internet]. 2020 Jun 3; Available from: http://dx.doi.org/10.1097/ INF.0000000000002788

27. Stadlbauer D, Amanat F, Chromikova V, Jiang K, Strohmeier $\mathrm{S}$, Arunkumar GA, et al. SARS-CoV-2 Seroconversion in $\mathrm{Hu}-$ mans: A Detailed Protocol for a Serological Assay, Antigen Production, and Test Setup [Internet]. Vol. 57, Current Protocols in Microbiology. 2020. Available from: http://dx.doi.org/10.1002/ cpmc. 100

28. Amanat F, Stadlbauer D, Strohmeier S, Nguyen T, Chromikova $\mathrm{V}$, McMahon $\mathrm{M}$, et al. A serological assay to detect SARSCoV-2 seroconversion in humans [Internet]. Available from: http://dx.doi.org/10.1101/2020.03.17.20037713

29. Hogan CA, Garamani N, Lee AS, Tung JK, Sahoo MK, Huang $\mathrm{C}$, et al. Comparison of the Accula SARS-CoV-2 Test with a Laboratory-Developed Assay for Detection of SARS-CoV-2 RNA in Clinical Nasopharyngeal Specimens [Internet]. Journal of Clinical Microbiology. 2020. Available from: http://dx.doi. org/10.1128/jcm.01072-20

30. Mohan SK, Veeraraghavan VP, Jainu M. Effect of pioglitazone, quercetin and hydroxy citric acid on extracellular matrix components in experimentally induced non-alcoholic steatohepatitis. Iran J Basic Med Sci. 2015 Aug;18(8):832-6.

31. G R, Ramya G, V VP, Gayathri R. CYTOTOXICITY OF STRAWBERRY EXTRACT ON ORAL CANCER CELL LINE [Internet]. Vol. 11, Asian Journal of Pharmaceutical and Clinical Research. 2018. p. 353. Available from: http://dx.doi. org/10.22159/ajpcr.2018.v11i9.25955 